\title{
ENGLANNIN KIELEN VAIKUTUKSIA KUUSIVUOTIAIDEN SUOMEA JA ENGLANTIA OMAKSUVIEN LASTEN SAMMAKKOTARINOISSA
}

\author{
Sonja Alantie, Tampereen yliopisto \\ Anna-Maija Korpijaakko-Huuhka, Tampereen yliopisto \\ Leena Rantala, Tampereen yliopisto
}

\begin{abstract}
Tutkimuksessa tarkasteltiin 11:n varhaisesti kaksikielisen 6-vuotiaan lapsen kielenkäyttöä suomeksi tuotetussa kuvakirjakerronnassa. Kaikkien lasten kotikieli oli suomi, minkä lisäksi he olivat omaksuneet englantia 0-4 vuoden iästä lähtien. Kertomuksista poimittujen epätyypillisten ilmaisujen avulla selvitettiin, miten englannin kielen omaksuminen mahdollisesti heijastui lasten kielellisiin valintoihin ja millaisia lasten ilmaisut olivat verrattuina yksikielisten ikäverrokeiden ( $n=10)$ ja vuotta nuorempien lasten $(n=12)$ ilmaisuihin. Lähes kaikki kaksikieliset lapset tuottivat jonkunlaisia epätyypillisiä ilmaisuja. Laatunsa perusteella ne pystyttiin jakamaan pääasiassa 1) englannin kielen vaikutuksesta johtuviin ja 2) suomen kielen omaksumiseen liittyviin. Kielten väliseen vaikutukseen liittyvien havaintojen perusteella kaksikieliset lapset tuottivat osittain hyvin erilaisia ilmaisuja kuin yksikieliset lapset, ja suomen kielen normista poikkeavia ilmaisuja esiintyi kaikkiaan hieman useammalla kaksikielisellä kuin yksikielisellä lapsella. Jotkin kaksikielisten lasten suomen kielen omaksumiseen liittyvät epätyypilliset ilmaisut sen sijaan muistuttivat heitä vuotta nuorempien verrokkilasten valintoja. Tulosten pohdinta nosti esille, että tutkimusympäristö ja tutkimuskäytänteet saattavat vaikuttaa kielen siirtymisherkkyyteen, mikä kannattaa ottaa kliinisessä työssä huomioon.
\end{abstract}

Avainsanat: kaksikielinen lapsi, kertova kieli, kielellinen valinta, kieltenvälinen vaikutus, systeemis-funktionaalinen kieliteoria

\section{JOHDANTO}

Lasten kaksikielisyys on maailmanlaajuisesti varsin yleistä (Kohnert, 2010), ja kaksikielisten lasten määrä tulee kasvamaan myös

Kirjoittajien yhteystiedot:

Sonja Alantie

Anna-Maija Korpijaakko-Huuhka

Leena Rantala

Yhteiskuntatieteiden tiedekunta/Logopedia

Kalevantie 4, 33014 Tampereen yliopisto

alantie.sonja.e@student.uta.fi

anna-maija.korpijaakko-huuhka@uta.fi

leena.m.rantala@uta.fi
Suomessa entisestään nykyisen maailmantilanteen aiheuttaman maahanmuuton myötä. Kaksikieliseen kielen kehitykseen liittyy useita erityispiirteitä. Ensinnäkin verrattuna yksikieliseen ikätoveriinsa kahden kielen vaikutuspiirissä kehittyvä lapsi omaksuu kahden eri kielen fonologian, leksikon ja rakenteellisten piirteiden lisäksi sen, miten kieliä käytetään kulttuurisesti asianmukaisilla tavoilla (Genesee, Paradis \& Crago, 2004, s. 27; Verhoeven, 2010, s. 436). Toiseksi kielten omaksumista määrittää myös se, että kaksikielinen lapsi saattaa altistua kullekin omaksumalleen 
kielelle suhteellisesti vähemmän kuin yksikielinen lapsi ainoalle kielelleen (Paradis, 2010). Lisäksi vuorovaikutustilanteiden laatu ja määrä vaihtelevat lapsen eri kielten kohdalla sen mukaan, kenen kanssa ja millaisiin diskurssitilanteisin lapsi pääsee osallistumaan (ks. Halliday, 1975, s. 5-6, 33; Leiwo, 1986, s. 70-72; Paradis, 2010).

Koska kaksikielisyys on monimuotoista, siihen liittyvä termistö on kirjallisuudessa laajaa ja osaltaan vakiintumatonta (esim. Wei, 2004). Tässä artikkelissa käytetään sanaa kaksikielinen kuvaamaan lapsia, jotka tarvitsevat ja käyttävät arjessaan kahta kieltä. Kielten täydellistä hallintaa tai samantasoisia taitoja molemmissa kielissä kaksikielisyys ei edellytä (ks. myös Skutnabb- Kangas, 1981, s. 89-90). Tarkemmin tutkimukseen osallistuneet kaksikieliset lapset on määritelty varhaisesti kaksikielisiksi ${ }^{1}$ (engl. dual language learner), sillä heidän altistumisensa kummallekin kielelle on alkanut ennen leikki-iän päättymistä, tässä tapauksessa ennen neljän vuoden ikää (Genesee ym., 2004, s. 218; Korpilahti, 2007).

Puheterapeuttien näkökulmasta kaksikielisyys ja sen monimuotoisuus luovat erityisiä vaatimuksia asiakkaan taustojen ja muiden hänen kielenkehitykseensä ja -käyttöönsä vaikuttavien tekijöiden tunnistamiseen ja tarkkaan selvittämiseen (Smolander, Kunnari \& Laasonen, 2016). Kaksikielisten lasten tyypillisestä kielenkehityksestä saati sitten poikkeavan kielenkehityksen piirteistä on kirjallisuudessa saatavilla niukasti tietoa asiantuntijatyön tueksi (ks. Bedore \& Peña, 2008; Kohnert, 2010). Tiedon puute johtaa toisinaan siihen, että kaksikielisillä lapsilla yli- tai alidiagnosoidaan kielellisiä häiriöitä,

\footnotetext{
1 Varbainen kaksikielisyys kattaa sekä samanaikaisen (simultaani) että peräkkäisen (suksessiivinen) kaksikielisyyden leikki-ikäisillä. Rajanveto näiden kahden tyypin välillä ei ole kirjallisuudessa täysin kiistaton (ks. esim. Arkkila, Smolander \& Laasonen, 2013; Costa \& Sebastián-Gallés, 2014; De Houwer, 2004).
}

koska tyypillisen kehityksen piirteitä ei tunnisteta ja luotettavat testauskeinot puuttuvat (Smolander ym., 2016; Bedore \& Peña, 2008; Kohnert, 2010).

Kielellisen erityisvaikeuden riskiä kaksikielisyys ei nykytiedon mukaan lisää, mutta siihen liittyy tyypillisesti kielellisten taitojen epätasaisuus ja suuri yksilöllinen vaihtelu (Arkkila, Smolander \& Laasonen, 2013; Kohnert, 2010). Useimmiten kaksikielisillä lapsilla toinen kielistä on dominantti eli paremmin hallittu (Dixon, Wu \& Daraghmeh 2012). Kielenkehitys tai omaksuminen voi olla myös hitaampaa joillain kielen osa-alueilla verrattaessa yksikielisiin ikätovereihin; esimerkiksi kaksikielisen lapsen yksittäisen kielen sanasto saattaa olla suppeampi kuin yksikielisillä lapsilla. Sen sijaan yhteenlaskettu kahden kielen sanasto on usein yhtä kattava tai kattavampi kuin yksikielisellä (Nicoladis, Rose \& Foursha-Stevenson, 2010).

Kielenkehitykseen kuuluvat niin yksi- kuin kaksikielisilläkin lapsilla kielen kehittymiselle tavanomaiset aikuiskielestä poikkeavat piirteet (ks. Kunnari \& Savinainen-Makkonen, 2012; Laalo, 2011). Tämän lisäksi kaksikielisen lapsen omaksuttavat kielet vaikuttavat toisiinsa, mikä saattaa johtaa erikoisiin ilmaisuihin (Nicoladis ym., 2010).

\section{KIELTENVÄLINEN VAIKUTUS}

Kaksikielisten lasten kielellisen tuoton yksi erityispiirre on juuri se, että heidän osaamansa kielet vaikuttavat toinen toisiinsa (Marian \& Kaushanskaya, 2007; ks. myös Kohnert, 2010; Weinreich, 1963). Kielten kontaktin aiheuttamia seurauksia ei ole kuitenkaan pystytty vielä määrittelemään tai luokittelemaan yksiselitteisesti (esim. Hoffmann, 1991, s. 94-96; Sajavaara, 2006). Kuvaamme tässä artikkelissa kielten vuorovaikutuksen ilmentymiä kattotermillä kieltenvälinen vaikutus (engl. cross-linguistic influences/interaction) 
(ks. Kaivapalu, 2005, s. 27-28, 30). Termillä tarkoitamme yksinkertaistetusti sitä, että yhden kielen elementtejä tuotetaan toisessa kielessä. Elementit voivat olla fonologisia, leksikaalisia, morfologisia, morfosyntaktisia, syntaktisia ja semanttisia (Genesee ym., 2004, s. 216; Hoffmann, 1991, s. 95-101).

Termi kieltenvälinen vaikutus kattaa tässä artikkelissa kirjallisuudessa nykyään usein toisistaan eritellyt käsitteet lainaaminen (engl. borrowing), yhdistäminen (engl. mixing/codemixing), kielenvaibto (engl. code-switching) sekä siirtovaikutus tai transfer ja interferenssi (engl. transfer ja interference) sekä mahdolliset muut kahden kielen kontaktista johtuvat kielelliset piirteet (ks. Hoffmann, 1991, s. 94-117; Marian \& Kaushanskaya, 2007). Kieltenvälinen vaikutus on yleistä kaikenikäisillä useita kieliä käyttävillä puhujilla, ja siihen vaikuttavat kielten säännönmukaisuudet sekä yksilölliset ja tilannekohtaiset tekijät (Genesee ym., 2004: 216; Weinreich, 1963, s. 1-6). Yhtäl̈lä puhujan kielenkehityksen vaihe ja toisaalta saavutetun kielellisen kompetenssin taso vaikuttavat kieltenvälisen vaikutuksen esiintymiseen. Kielten yhdistäminen ja kielenvaihto ovat myös erityisesti sosiopragmaattisesti ja yhteisöllisen viestinnän näkökulmasta tärkeitä (Richie \& Bhatia, 2013). Kielten yhdistämistä ja vaihtoa nimittäin säätelevät paljolti sosiaaliset ja ilmaisulliset motivaattorit kuten keskustelukumppaneiden roolit, puheenaiheet, turvallisuuden tunne ja yhteisön asenteet tai kielen status.

Kieltenväliset vaikutukset voivat olla sekä tietoisia että tiedostamattomia valintoja. Nykyisen neurokognitiivisen käsityksen mukaan kaksikielisten henkilöiden kaikki kielet ovat aina aktivoituneina (Linck, Hoshino \& Kroll, 2008). Useimmiten kaksikielinen henkilö pystyy kontrolloimaan, miten hän taitojensa puitteissa kieliään käyttää (Costa \& Sebastián-Gallés, 2014; ks. myös Ijalba, Obler \& Chengappa, 2013). Kaksikieliseksi kehittyvien lasten kielellisiin valintoihin vaikuttavat sekä lapsen oma kielikompetenssi että vanhempien antama malli. Yipin ja Matthewsin (2006) tutkimuksessa syntymästään asti kahta kieltä omaksuneilla lapsilla (kielet: kantoninkiina ja englanti, $\mathrm{N}=6$, iän vaihteluväli 1;03-4;06) syntaktisten rakenteiden todettiin siirtyvän (engl. syntactic transfer) lähes yksinomaan lasten paremmin hallitsemasta kiinan kielestä heikommin hallittuun englannin kieleen (Yip \& Matthews, 2006). Kielten yhdistäminen (code-mixing) oli sen sijaan epäsymmetrisempää, ja tutkijat katsoivat sen johtuvan aikuisten mallista käyttää englannin kielen sanoja kiinan seassa (ks. myös suomienglanti-kaksikielisten perheiden vanhempien kielikasvatuksen periaatteista Morris \& Korpijaakko-Huuhka, 2009).

Myös omaksuttavien kielten typologia eli perusrakenne ja käytön ominaisuudet sekä se, miten kielet lapsella tyypillisesti kehittyvät, vaikuttavat siihen, minkälaisia seurauksia niiden keskinäinen kontakti aiheuttaa. Tietynlaisten rakenteiden siirtyminen on kiinaa ja englantia tutkineiden Yippin ja Mathewsin (2000) mukaan ylipäätään mahdollista kielten keskinäisen erilaisuuden vuoksi, sillä samanlaisia piirteitä ei havaita kaksikielisillä, joiden kielipareina ovat sukulaiskielet. Toisaalta kontaktoivien kielten typologisen läheisyyden ja rakenteellisen samankaltaisuuden on havaittu johtavan runsaaseen kieltenväliseen vaikutukseen (Riionheimo, 2010). Englannin kielen vaikutusta suomea puhuvien kaksikielisten lasten valintoihin on tutkittu melko vähän (esim. Halmari, 1997; Halmari, 1997, s. 35-36; Poplack, Wheeler \& Westwood, 1989). Suomalais-amerikkalaisten nuoriksi varttuvien lasten kielen vaihtoa ja yhdistämistä (code-switching) tarkastelevassa seurantatutkimuksessa (kielet: ensikieli = suomi ja toinen kieli = englanti, $\mathrm{N}=2$ ) havaittiin, että kielenvaihto johtui jonkin kielenkäyttötilanteen sanastopuutteiden paikkaamisesta tai 
ilmaisullisista tavoitteista (Halmari, 2005). Myös toisessa tutkimuksessa (kielet: ensikieli = suomi ja toinen kieli = englanti, $\mathrm{N}=2$ ) kaksikieliset lapset vaihtoivat leikeissään kieltä sen mukaan, puhuivatko he leikin hahmoina vai neuvottelivatko he leikkimisestä (Halmari \& Smith, 1994).

Usean kielen vaikutuspiirissä kasvamisella ja kahden kielen omaksumisella on siis havaittu olevan vaikutuksia lapsen kielenkäyttötapoihin ja -taitoihin. Kaksikielisten lasten kielenkäytön piirteitä ei kuitenkaan välttämättä osata aina tulkita asianmukaisesti tarvittavan tutkimustiedon puuttuessa.

\section{TUTKIMUKSEN TARKOITUS}

Suomalaisten puheterapeuttien tarve tunnistaa tavanomaisella tavalla monikieliseksi kehittyvät ja erityistukea ja kielellistä kuntoutusta tarvitsevat lapset on korostunut erityisesti sitä mukaa, kun maahanmuutto noin 20 vuotta sitten alkoi kiihtyä (Arkkila ym., 2013; Kohnert, 2010; Rapo, 2012). Pätevien arviointimenetelmien kehittämiseksi tarvitaan tietoa kaksikielisten suomen puhujien kielenkehityksen ja -käytön piirteistä. Suomessa logopedinen kaksikielisyystutkimus on vielä niukkaa, ja kaksikielisten lasten kielenkehityksen arviointiin on kehitetty vasta muutamia menetelmiä (Korpilahti, 2010; ks. myös Chakraborty, 2015). Kansainvälisestikin on tutkittu lähinnä romaanisia ja germaanisia kieliä (Chakraborty, 2015; Silvén, 2010, s. 142), mutta näiden tutkimusten tuloksia ei voida suoraan yleistää suomea puhuviin kaksikielisiin ihmisiin. Siksi kielikohtaiselle tutkimustyölle on selvä tarve.

Tämän tutkimuksen tavoitteena oli arvioida, miten kaksikielisten suomea ja englantia puhuvien lasten suomenkielisessä kerronnassa näkyi mahdollinen englannin kielen vaikutus. Tutkimus nojautuu teoreettisesti systeemisfunktionaaliseen kieliteoriaan (Halliday,
1985) ja sosiaalisen konstruktivismin mukaiseen ajatteluun kielen oppimisesta (Vygotsky, 1982). Systeemis-funktionaalisen kieliteorian mukaan kukin kieli on kulttuurisidonnainen merkkijärjestelmänsä, joka tarjoaa puhujalle puitteet merkitysten tuottamiseen (Halliday \& Matthiessen, 2004, s. 19-31; Shore, 1992, s. 22-23). Kokonaisuudessaan kaksikielisen lapsen kielellinen resurssi koostuu siis kahteen järjestelmään liittyvistä taidoista. Järjestelmät kehittyvät alati sosiaalisessa vuorovaikutuksessa lapsen havaitsemien ja järkeilemien säännönmukaisuuksien kautta (ks. Laalo, 2011, s. 269-273; Vygotski, 1982, 104, 185).

Lasten ilmauksia kutsumme Hallidayn tapaan kielellisiksi valinnoiksi (Halliday, 1985, s. xxvii). Termillä viitataan siihen, että puhuja valitsee joko tietoisesti tai tiedostamattaan tavan ilmaista asioita aina sekä kielellisten taitojensa että kielen käyttötilanteen mukaisesti (Halliday, 1973, s. 48-58). Tutkimuksessa oletimme, että kaksikielisten lasten valinnoissa näkyisi kerrontadiskurssissa juuri heille ominaisia tapoja toteuttaa omaksumiensa kielisysteemien merkityspotentiaaleja (ks. Halliday, 1985, s. xxix-xxx; Shore, 1992, s. 21-24).

Tarkastelemme tutkimuksessa vain kaksikielisten lasten niin sanotusti epätyypillisiä ilmaisuja, mutta emme käsittele niitä vuorovaikutuksen tai kielen hallinnan kannalta huonoina valintoina tai virheinä. Tutkimme kielen vaikutusta toiseen epätyypillisten ilmausten kautta yksinkertaisesti siksi, että se oli tällä tavalla verrattain helpompi havaita ja perustella. Kieltenvälinen vuorovaikutushan tuottaa myös tavanomaisia tai niin sanotusti oikeellisia ilmaisuja ja eri kielet voivat tukea toistensa kehittymistä monin tavoin (Cummins, 2001; Kaivapalu, 2005; Nicoladis ym., $2010)^{2}$.

\footnotetext{
2 Kielten välinen vaikutus jaetaan usein kirjallisuudessa positiiviseen ja negatiiviseen vaikutukseen (ks. esim. Kaivapalu, 2005: 24-38).
} 


\section{AINEISTO JA MENETELMÄT}

\section{Tutkittavat}

Tutkimuksessa oli mukana 11 lasta Tampereen seudun englanninkielisistä esikouluista. ${ }^{3}$ Opettajat valitsivat tutkimuksiin lapsia, jotka käyttivät arjessaan sekä suomea että englantia ja jotka pystyivät opettajan arvion mukaan tuottamaan kertovaa kieltä. Lapsilla ei ollut todettu kielellisiä häiriöitä, eivätkä he olleet puheterapeuttisten palveluiden piirissä. ${ }^{4}$ Lasten vanhemmilta pyydettiin kirjallinen suostumus tutkimukseen osallistumisesta, ja he täyttivät lomakkeen lapsen kielenkehityksestä ja -käytöstä. ${ }^{5}$

Lasten äidin tai molempien vanhempien äidinkieli oli suomi. Yhdenkään lapsen vanhemman äidinkieli ei ollut englanti, eivätkä lapset olleet omaksuneet toisen vanhemman kieltä sen ollessa muu kuin suomi. Suurin osa lapsista oli alkanut altistua englannille mennessään englanninkieliseen päiväkotiin Suomessa tai muuttaessaan ulkomaille. $\mathrm{Mu}$ kana oli yksi lapsi, joka oli alkanut omaksua englantia kotonaan syntymästään asti. Hän kuitenkin muistutti muita tutkimukseen otettuja kaksikielisiä lapsia siksi, että äidin puhumalla kielellä eli tässä suomella voidaan joidenkin tutkimusten mukaan katsoa olevan varsinkin varhaislapsuudessa isän kieltä vahvempi vaikutus kielenkehitykseen (Place \& Hoff, 2011).

Lapsista seitsemän oli poikia ja neljä tyttöjä (iän vaihteluväli 6;0-6;9) (taulukko 1). Tutkimushetkellä kaikki lapset käyttivät koto-

\footnotetext{
3 Kaksikieliset lapset kuuluivat kaksikielisten lasten verbien käyttöä kuvanneen pro gradu -tutkimuksen tutkittavien joukkoon (Alantie, 2014)

4 Kaksikielisiä lapsia tai verrokkeja ei ole tutkimusta varten testattu standardoiduin logopedisin testein.

5 Alkuperäinen kyselylomake on Anne Suvannon (2012) laatima. Sitä ovat soveltaneet tutkimuksessaan Eriksson ja Rajala (2014), ja sitä on muokattu edelleen muutamin kaksikielisyyttä käsittelevin kysymyksin.
}

naan ainakin suomea ja esikoulussa englantia. Usein lasten kerrottiin käyttävän englantia joissakin tilanteissa myös kotona. Taulukossa 1 vahvimmaksi merkitty kieli oli vanhemman arvio siitä, mikä on lapsen parhaiten osaama kieli. Tutkittavista käytetään tunnistetta, jossa CG viittaa tyttöön ja $\mathrm{CB}$ poikaan $(\mathrm{C}=$ child, $\mathrm{G} / \mathrm{B}=$ girl/boy).

Kaksikielisten lasten verrokkeina toimi 22 suomenkielistä lasta, jotka olivat osallistuneet Tampereen yliopiston logopedian oppiaineessa tehtyihin lasten kerrontaa koskeviin tutkimuksiin. Verrokeiksi valittiin kaksikielisten lasten kanssa samanikäisten lasten lisäksi vuotta nuorempia, sillä on esitetty, että kahden kielen omaksuminen saattaa hidastaa kielenkehitystä joillakin kielen osaalueilla (Arkkila ym., 2013). Verrokkilapsista kuusi tyttöä ja neljä poikaa oli kuusivuotiaita (iän vaihteluväli 6;4-6;11) (ks. lapsista tietoja tarkemmin Eriksson \& Rajala, 2014; Roininen, 2014). Viisivuotiaita valittiin 12 ja heistä puolet oli tyttöjä ja puolet poikia (iän vaihteluväli 5;1-5;9) (ks. lapsista tietoja tarkemmin Mertanen \& Vaarma, 2015). Verrokeille annettiin tunnisteet seuraavasti: $\mathrm{L}=$ yksikielinen lapsi, $\mathrm{T} / \mathrm{P}=$ tyttö/poika, $\mathrm{K} / \mathrm{V}=$ kuusi-/viisivuotias ja numero. 
Taulukko 1. Kaksikielisten kuusivuotiaiden lasten taustatiedot.

\begin{tabular}{|c|c|c|c|c|c|c|c|c|}
\hline Lapsi & Ikä & L1 (0) & \begin{tabular}{|l|} 
L2 \\
(omak- \\
sumisen \\
alkamisikä) \\
\end{tabular} & \begin{tabular}{|l|} 
Vanhempien \\
äidinkielet \\
ja yhteinen \\
kieli \\
\end{tabular} & $\begin{array}{l}\text { Missä } \\
\text { käyttää } \\
\text { suomea? }\end{array}$ & $\begin{array}{l}\text { Missä } \\
\text { käyttääa } \\
\text { englantia? }\end{array}$ & $\begin{array}{l}\text { Vahvin } \\
\text { kieli }\end{array}$ & $\begin{array}{l}\text { Asunut } \\
\text { ulko- } \\
\text { mailla }\end{array}$ \\
\hline CG2 & $6 ; 8$ & \begin{tabular}{|l|} 
suomi \\
(isä \\
puhunut \\
myös \\
arabiaa)
\end{tabular} & \begin{tabular}{|l|} 
englanti (3); \\
varsinaisesti \\
vasta \\
päiväkodissa
\end{tabular} & $\begin{array}{l}\text { äiti: suomi } \\
\text { isä: arabia } \\
\text { yhteinen } \\
\text { kieli: englanti }\end{array}$ & $\begin{array}{l}\text { kotona } \\
\text { äidin ja } \\
\text { sisarusten } \\
\text { kanssa }\end{array}$ & \begin{tabular}{|l|} 
päiväkodissa \\
ja kotona \\
isän ja \\
sisarusten \\
kanssa
\end{tabular} & $\begin{array}{l}\text { suomi } \\
\text { ehkä } \\
\text { hieman }\end{array}$ & ei \\
\hline CB3 & $6 ; 7$ & suomi & englanti (3) & suomi & kotona & $\begin{array}{l}\text { päiväkodissa } \\
\text { ja kotona }\end{array}$ & suomi & kyllä \\
\hline CB4 & $6 ; 4$ & suomi & englanti (3) & suomi & kotona & päiväkodissa & suomi & kyllä \\
\hline CB6 & $6 ; 3$ & suomi & englanti (3) & suomi & kotona & $\begin{array}{l}\text { päiväkodissa } \\
\text { ja kotona }\end{array}$ & suomi & kyllä \\
\hline CG8 & $6 ; 1$ & suomi & englanti (4) & suomi & kotona & $\begin{array}{l}\text { päiväkodissa } \\
\text { ja kotona }\end{array}$ & suomi & kyllä \\
\hline CB9 & $6 ; 7$ & suomi & englanti (3) & suomi & kotona & $\begin{array}{l}\text { päiväkodissa } \\
\text { ja kotona }\end{array}$ & suomi & kyllä \\
\hline CG10 & $6 ; 7$ & suomi & englanti (3) & suomi & kotona & $\begin{array}{l}\text { päiväkodissa } \\
\text { ja kotona }\end{array}$ & suomi & kyllä \\
\hline CG12 & $6 ; 7$ & suomi & englanti (2) & suomi & kotona & päiväkodissa & suomi & ei \\
\hline CB16 & $6 ; 0$ & suomi & englanti (2) & suomi & kotona & $\begin{array}{l}\text { päiväkodissa } \\
\text { ja kotona }\end{array}$ & $\begin{array}{l}\text { suomi } \\
\text { tällä } \\
\text { hetkellä }\end{array}$ & kyllä \\
\hline CB18 & $6 ; 9$ & suomi & $\begin{array}{l}\text { ruotsi } \\
(1 ; 1-2 ; 6) ; \\
\text { englanti (3) }\end{array}$ & suomi & kotona & päiväkodissa & \begin{tabular}{|l|} 
suomi ja \\
englanti \\
ehkä \\
yhtä \\
vahvat
\end{tabular} & kyllä \\
\hline CB20 & $6 ; 4$ & $\begin{array}{l}\text { suomi ja } \\
\text { englanti }\end{array}$ & - & $\begin{array}{l}\text { äiti: suomi } \\
\text { isä: amhara, } \\
\text { yhteiset } \\
\text { kielet } \\
\text { englanti ja } \\
\text { suomi }\end{array}$ & kotona & $\begin{array}{l}\text { päivä- } \\
\text { kodissa ja } \\
\text { kotona }\end{array}$ & $\begin{array}{l}\text { suomi } \\
\text { ehkä } \\
\text { hieman }\end{array}$ & ei \\
\hline
\end{tabular}

$\mathrm{C}=$ kaksikielinen lapsi (child), $\mathrm{G}=$ tyttö (girl), $\mathrm{B}=$ poika (boy), $\mathrm{L} 1$ = syntymästä asti omaksuttu eli ensikieli, L2 = toisena omaksuttu kieli 


\section{Aineistonkeruu ja analyysi}

Tutkimuksen kerrontamateriaalina käytettiin sammakkotarinaa (Frog, where are you? Mayer, 1969), joka on kerronnantutkimuksissa usein hyödynnetty tekstitön kuvasarja (esim. Berman \& Slobin, 1994; Suvanto, 2012). Verrokkilasten sammakkotarinat saatiin valmiina litteraatteina. Kaksikieliset lapset ohjeistettiin kertomaan kirjasta tarkasti ja omin sanoin tarina ensin englanniksi ja heti sen perään suomeksi ${ }^{6}$. Kerrontatilanteet nauhoitettiin ja litteroitiin. ${ }^{7,8}$ Lopullisena tutkittavana kieliaineistona oli lasten käyttämät ilmaisut kertomuksessa sekä lasten kysymykset ja kommentit tutkijalle tehtävän aikana, sillä esimerkiksi kielenvaihtoa voi tapahtua puheen tyylin tai tavoitteen vaihtumisen yhteydessä (Halmari, 2005; Halmari \& Smith, 1994).

Tutkimuksen analyysi oli pääasiassa laadullista. Aluksi kaksikielisten lasten suomenkielisistä kertomuksista poimittiin ilmaukset, jotka arvioitiin jollakin tavalla epätyypillisiksi tai virheellisiksi. Epätyypillisyyden määrittelemiseksi lasten valintoja verrattiin nykysuomessa kuvattuihin säännönmukaisuuksiin, kuten tehdään usein myös vieraan kielen oppimisen ja välikielen (engl. second language learningja interlanguage) tutkimuksissa virheanalyysin periaatteiden mukaisesti (ks. virheanalyysi Aalto ym., 1997; Corder, 1981, s. 37). Epätyypillisyydellä viitataan tässä siihen, että ilmaisu ei ole suomalaisessa kielikulttuurissa tavanomainen eikä vastaa ai-

\footnotetext{
${ }^{6}$ Kielijärjestys on ollut alkuperäiseen tutkimukseen liittyvä (Alantie, 2014) metodologinen valinta, jolla on pyritty varmistamaan englanninkielen aineiston saaminen. Kielijärjestys ja ohjeistus ovat olleet kaikille lapsille samat.

7 Aineistonkeruu ja litterointi on kuvattu tarkemmin pro gradu -tutkielmissa Alantie (2014) ja (2015)

8 Kaksikielisten lasten tarinalitteraatit ovat pyydettävissä kirjoittajalta. Verrokkilasten litteraateista kyselyt osoitetaan Tampereen yliopiston logopedian oppiaineeseen.
}

kuiskielessä kuvattuja ilmaisutapoja. Pyrimme tunnistamaan suomen kielen puhekielisyydet, murreilmaisut sekä itsekorjaukset, jotta niitä ei tulkittaisi epätyypillisiksi ilmaisuiksi. Selvästi keskenjääneitä ja epäselviä puhunnoksia ei analysoitu lainkaan.

Jos epätyypillinen suomenkielinen ilmaisu vastasi lapsen itsensä tuottamaa englanninkielistä ilmaisua, se luokiteltiin kieltenvälisestä vaikutuksesta johtuvaksi. Kaikkia oletetusti englannin kielen vaikutusta sisältäviä ilmauksia verrattiin myös verrokkilasten tapaan ilmaista sama tarinan tapahtuma (ks. myös Yip ja Matthews, 2000). Kaksikielisten lasten ilmaukset, joissa englannin kielen vaikutus voitiin havaita, luokiteltiin kielellisen osaalueensa mukaan (taulukko 2).

Ne kaksikielisten lasten poikkeavat ilmaisut, jotka eivät vaikuttaneet sopivan englannin kielen vaikutuksesta johtuviksi, luokiteltiin erikseen (taulukko 3). Nämä ilmaisut määriteltiin tässä tutkimuksessa suomen kielen omaksumiseen liittyviksi eli sellaisiksi, joita lapset voivat tuottaa kehittyessään kohti aikuismaisia vakiintuneita muotoja, olivatpa he sitten yksi- tai kaksikielisiä (ks. esim. Laalo, 2011; 121-142). Poikkeamia tarkasteltiin sekä kaksikielisten että yksikielisten lasten aineistossa. Tässä luokituksessa ei tarkasteltu lainkaan lasten äänteistöä.

Analyysin reliabiliteettia varmistettiin mahdollisimman ajantasaisten deskriptiivisten sanakirja- ja kielioppilähteiden avulla (Kielitoimiston sanakirja, 2015; Oxford Language Dictionaries Online [tästedes OLDO, 2015] ja MOT-suursanakirja, 2015 ja VISKverkkokielioppi, 2015). Useissa yksittäistapauksissa konsultoitiin myös logopedian sekä suomen kielen ja englannin kielen asiantuntijoita. 
Taulukko 2. Kieltenvälisestä vaikutuksesta johtuvien epätyypillisten ilmauksien luokat ja niiden ilmeneminen lapsen kielellisessä valinnassa.

\begin{tabular}{|l|l|}
\hline KIELTENVÄLINEN VAIKUTUS & ILMENEMINEN VALINNASSA \\
\hline Äänteistö & $\begin{array}{l}\text { Lapsi tuottaa englannille tyypillisiä äänteitä } \\
\text { suomeksi kertoessaan }\end{array}$ \\
\hline Sanasto & $\begin{array}{l}\text { Lapsi tuottaa yksittäisen englanninkielisen sanan } \\
\text { muutoin suomenkielisessä ilmauksessa }\end{array}$ \\
\hline Pidemmät ilmaukset & $\begin{array}{l}\text { Lapsi tuottaa pidemmän ilmaisun englanniksi } \\
\text { suomeksi suoritettavan tehtävän aikana } \\
\text { lausumansisäisesti tai lausumienvälisesti eli lapsi } \\
\text { vaihtaa välillä kieltä }\end{array}$ \\
\hline Morfologia, syntaksi tai morfosyntaksi & $\begin{array}{l}\text { Lapsi tuottaa englannin kielessä olevaa } \\
\text { rakennetta muistuttavan rakenteen tai englannin } \\
\text { kielestä johdetun rakenteen, mutta käyttää } \\
\text { suomenkielistä sanastoa. }\end{array}$ \\
\hline Idiomaattinen ilmaus* & $\begin{array}{l}\text { Lapsen ilmaus muistuttaa jotakin } \\
\text { englanninkielistä idiomaattista eli } \\
\text { konventionaalista ilmaisutapaa. Ilmaus ei } \\
\text { välttämättä ole suomeksi rakenteeltaan huono tai } \\
\text { asiayhteydessään käsittämätön. Tästä huolimatta } \\
\text { ilmaus on kulttuurikontekstissaan epätyypillinen, } \\
\text { eli suomen kielestä löytyisi jokin vakiintuneempi } \\
\text { tapa ilmaista asia. Sanasto on suomenkielistä. }\end{array}$ \\
\hline Muu & $\begin{array}{l}\text { Englannin kielen vaikutus on jotenkin } \\
\text { havaittavissa kielellisessä valinnassa, } \\
\text { mutta tapaus ei sovi yllä oleviin luokkiin tai } \\
\text { ilmaisutavasta löytyy vain yksittäinen esimerkki }\end{array}$ \\
\hline
\end{tabular}

* Idiomaattisilla ilmauksilla (idiom) tarkoitamme luokittelussamme kaikenlaisia kielellisiä kiteytymiä eli ilmaisutapoja, jotka ovat ominaisia jollekin tietylle kielelle, kansalle tai ryhmälle (Nenonen, 2002; OLDO, 2015).

Taulukko 3. Kieltenvälisestä vaikutuksesta johtumattomien epätyypillisten ilmausten luokat ja niiden ilmeneminen lapsen kielellisessä valinnassa.

\begin{tabular}{|l|l|}
\hline EPÄTYYPILLINEN ILMAUS TAI VIRHE & ILMENEMINEN VALINNASSA \\
\hline Äänteistö & Ei tarkastelussa \\
\hline Sanasto & $\begin{array}{l}\text { Lapsi tuottaa vääriä sanoja tai muodostaa } \\
\text { "omia sanoja" eli uudissanoja }\end{array}$ \\
\hline Morfologia, syntaksi tai morfosyntaksi & $\begin{array}{l}\text { Lapsen sanatasoinen morfologia tai } \\
\text { lausetasoinen syntaksi tai morfosyntaksi on } \\
\text { poikkeavaa }\end{array}$ \\
\hline Idiomaattinen ilmaus & $\begin{array}{l}\text { Lapsen ilmaisutapa saattaa olla kontekstissaan } \\
\text { ymmärrettävä, mutta suomen kielestä löytyisi } \\
\text { jokin vakiintuneempi tapa ilmaista asia }\end{array}$ \\
\hline Muu & $\begin{array}{l}\text { Ilmaus ei sovi yllä esitettyihin luokkiin tai on } \\
\text { erityisen tulkinnanvarainen }\end{array}$ \\
\hline
\end{tabular}




\section{TULOKSET}

Kaikkien tarkastelemiemme ryhmien lapset tuottivat kertomuksissaan jonkinlaisia epätyypillisiä ilmauksia. Epätyypillisten ilmausten määrä vaihteli lapsesta toiseen suuresti, joten niiden laskeminen ryhmätasolla ei ollut mielekästä. Sen sijaan on laskettu, kuinka monella lapsella ilmauksia esiintyi ylipäätään. Epätyypilliset ilmaukset olivat jonkin verran yleisempiä kaksikielisillä (10:1lä 11:sta) kuin yksikielisillä ikäverrokeilla (6/10) tai vuotta nuoremmilla lapsilla (9/12). Kaksikielisten lasten tuottamat suomenkieliset epätyypilliset ilmaisut olivat kahdentyyppisiä: 1) kielellisissä valinnoissa näkyi kieltenvälinen vaikutus ja 2) kielellisissä valinnoissa ei näkynyt kieltenvälistä vaikutusta, vaan epätyypillisyyksien katsottiin liittyvän suomen kielen omaksumiseen. Aineistosta löytyi myös ilmauksia, jotka mahdollisesti 3) edustivat sekä kieltenvälistä vaikutusta että suomen kielen omaksumisprosessiin liittyviä muotoja, tai niitä oli vaikea erottaa toisistaan. Kieltenvälisen vaikutuksen aiheuttamiksi tulkittuja ilmaisuja oli suurimmalla osalla kaksikielisistä lapsista (7/11) samoin kuin englannin kielen vaikutuksesta johtumattomia $(8 / 11)$.

\section{Englanninkielisten äänteiden, sanojen ja pidempien ilmausten siirtyminen suomeen}

Kaksikieliset lapset olivat omaksuneet ensikielenään suomea, eikä englannin kieli ollut kuulonvaraisen tarkastelun perusteella vaikuttanut lasten äänteisiin tai aksenttiin. Yhdellä lapsella englanti vaikutti havaittavasti kuitenkin suomen kielen epäröintiäänteisiin (esimerkki 1).
Esimerkki 1: Aamm

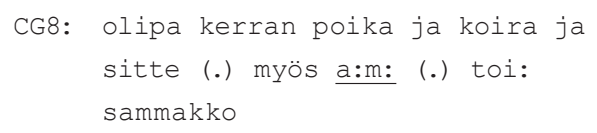

Tyttö käytti samaa englannin kielelle tyypillistä epäröintiäännettä (OLDO, 2015) johdonmukaisesti sekä suomenkielisessä että englanninkielisessä kerronnassaan: and then (.) um the cup broke. ${ }^{9}$ Yksikieliset lapset puolestaan saattoivat ilmaista epäröintiään suomalaiskulttuurille hyvin ominaisella tavalla, kuten kuusivuotias tyttö LTK3 tässä: $\underline{000} o$ - olipa kerran poika jolla oli ôö sammakko (VISK, 2015, § 1004).

Englantia yhdistyi suomeen myös sanatasolla, kun lapsi haki toisesta kielestä tukea kuvailutarkoitukseen. Kaksi poikaa tuotti englannin kielelle tyypillisen onomatopoeettisen ilmauksen elävöittääkseen tarinan äänimaailmaa (esimerkki 2).

\section{Esimerkki 2: Splash!}

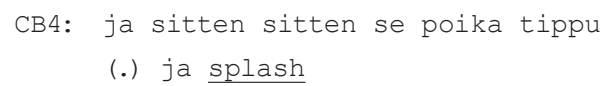

Pojat käyttivät samaa ilmausta myös englanniksi kertoessaaan: an' den he (.) go+in + de water an'plash (CB4); boy and do:gfell down (.) in with a big splash (CB20). Vaikka veteen putoamisesta syntyvää ääntä kuvaava sana oli myös suomalaisessa kontekstissa ilmaisuvoimainen, se ei ole kielellemme tyypillinen. Yksikieliset lapset tuottivatkin saman asiasisällön toisin: sitten tuli k-kuulu loiskiks (LPK2); hirvi tiputtipojan ja koiran sinne [...] veteen ja sitten sinne loiskahti (LTV7); sitten be molskabtivat veteen (LTK1).

\footnotetext{
9 Huom. kielten erilaisen ortografian vuoksi epäröintiäänteen kirjoitusasu vaihtelee, vaikka ääntämys on sama
} 
Eräs kaksikielinen lapsi vaihteli kerrontansa aikana kieltä tuottamalla suomen lomaan kokonaisia lauseita englanniksi (esimerkki 3).

Esimerkki 3: I'm not very good at Finnish ( $\mathrm{T}=$ tutkija)

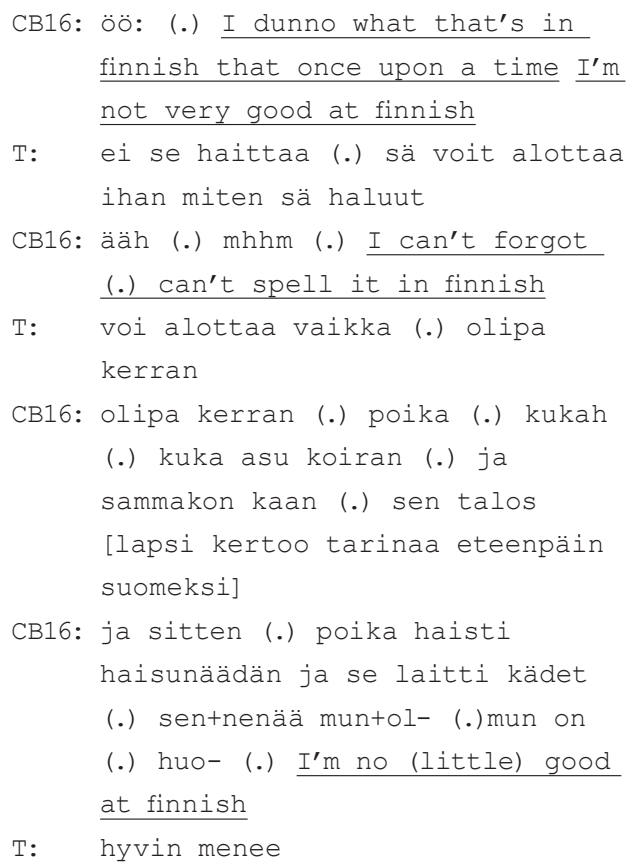

Esimerkissä 3 on kyse kielen- tai koodinvaibdosta diskurssitilanteen sisällä (engl. code-switching). Pojan koodinvaihto saattoi olla tapa helpottaa omaa kielellistä tuottoa, kun suomenkielinen vastine ei tullut heti mieleen. Usein koodinvaihdolla on myös vahvasti pragmaattinen tarkoitus (Meisel, 2004), ja kielenvaihdon retorinen tavoite saattoi tässä viestiä tutkijalle kyllästymistä tehtävään. Poika vaihtoi kieltä erottaen tehtävän kommentoinnin varsinaisesta kerronnastaan, joten hän saattoi haluta näin ehkä korostaa kommenttejaan.

\section{Englannin kielen siirtyminen suomen syntaksiin ja morfosyntaksiin}

Tässä aineistossa englanti vaikutti usein ilmaisujen rakenteeseen ja semantiikkaan.
Aiemmassa esimerkissä 2 näkyy, että lause sielä oli iso splash sisältää englanninkielisen sanan lisäksi suomalaisittain erikoisen syntaktisen rakenteen, joka vastaa englanninkielessä tavallista jossakin on jotakin eli there is/ are -rakennetta (vrt. there was a big splash) (ks. OLDO, 2015). Lapsi käytti rakennetta itsekin muita tarinan tapahtumia kertoessaan (esim. CB20: and in de+oder side (.) there were two frogs).

Joillakin lapsilla sijapäätteiden valinta tuotti erikoisia ilmaisuja. Englannissa käytetään prepositioita, kun taas suomessa vastaavat merkitykset tuotetaan usein sijapäätteillä (Hakulinen ym., 2004: 197-216). Englannin kielen prepositioilla on yleensä useita merkityksiä (Lindstromberg, 2010). Siten ne myös kääntyvät suomalaisiksi sijapäätteiksi tai omiksi sanoikseen tilannekohtaisesti, mikä saattoi aiheuttaa hankaluuksia myös lapselle esimerkissä 4 .

Esimerkki 4: Pois mehiläisist

CB16: koira meni poi- (.) juoksi pois mehiläisist

Esimerkkiä 4 vastaavassa englanninkielisessä kuvauksessa lapsi käytti prepositiota from: the do: $g$ (.) ran away from deh bees. Tämä prepositio kääntyy suomeksi muun muassa juuri päätteillä -sta ja -stä (MOT, 2015). Lapsi CB16 oli mahdollisesti valinnut epäsopivan sijapäätteen yrittäessään tuottaa englannin kielen sanan from edustaman spatiaalinen suhdemerkityksen suomeksi. Valintaan on saattanut vaikuttaa myös suomenkielen poissanan tyypillinen käyttö muissa asiayhteyksissä, esim. pois talosta tai pois edestä (VISK, 2015, § 1235). Samaa tapahtumaa kuvatessaan yksikieliset lapset tekivät erilaisia valintoja, kuten koila juoksi äkkiä pois ampiaisten luota (LTV6); koira läbti (.) pakoon mehiläisiä (LPK5); koira meni karkuun (LTK7). 


\section{Englannin kielen idiomaattisten ilmausten siirtyminen suomeen}

Aineistosta löytyi eniten havaintoja siitä, että englannin kielen idiomaattiset ilmaukset olivat oletettavasti vaikuttaneet lapsen kielellisiin valintoihin (esimerkit 5-9). Jo esimerkissä 3 tuli esille, että sadun aloittaminen suomeksi oli pojalle vaikeaa mahdollisesti siksi, että hän ei tiennyt tai muistanut tekstilajityypillistä aloitusfraasia. Kaksi lasta (CB9 ja CG10; esimerkki 5) puolestaan hyödynsi samassa tilanteessa englannin kielestä tuntemaansa fraasirakennetta once (upon a time) there was/mun vastaava verbi + subjektilauseke (esim. CG10: once upon a time there lived a little boy who had a frog: (.) in a (.) this kind+ofjar) (ks. OLDO, 2015).

Esimerkki 5: Yhden kerran oli

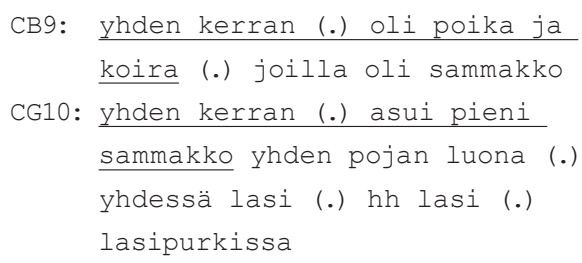

Kuusivuotiaat verrokit saattoivat aloittaa sammakkotarinansa idiomaattisesti olipa kerran, mutta yleisimmin hekin tekivät sen jollakin muulla tavalla, esimerkiksi: no oli semmonen poika ja koira (LTK4); sillee että alussa (.) noilla noi- on yö...(LTK10); eräänä iltana (.) koira nuuskisi ybtä purkkia missä oli sammakko (LTK1). Viisivuotiaat eivät juuri tuottaneet fraaseja vaan aloittivat usein kuvaamalla kuvissa esitettyjä olioita tai tapahtumia esimerkiksi näin: koira kattoo purkkiin (LPV17); tuolla on sammakko (.) tuolla on koila joka kattoo tonne tölkkiin...(LPV5). Kaikissa lapsiryhmissä lapset kuitenkin näyttivät useimmiten tietävän, että kertomuksessa on ensimmäisenä jollakin tavalla kuvattava tarinan lähtötilanne (Korpijaakko-Huuhka, 2011). Genretietoisuus siis luultavasti aiheutti myös esimerkin
5 kaksikielisille lapsille tarpeen kehittää tarinansa alkuun jonkinlainen lauseparsi, vaikka lapset eivät tutkimustilanteessa löytäneetkään suomen kieleen vakiintunutta aloitusfraasia.

Esimerkin 6 epätavallinen ilmaus muistutti englannin kielelle tyypillistä tapaa kuvata vaatekappaleisiin ja asusteisiin sonnustautumista (put on) (MOT, 2015).

Esimerkki 6: Kengät päälleen

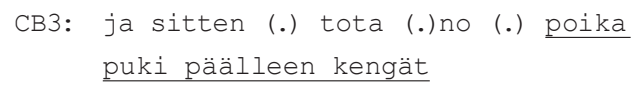

Toisin kuin esimerkkilauseessa 6, suomessa on tapana sanoa, että kengät pannaan tai laitetaan jalkaan (Kielitoimiston sanakirja, 2015; MOT, 2015). Pojan tuotokseen saattoivat yhtälailla vaikuttaa sekä vaatteiden pukemiseen liittyvä ilmaisutapa suomessa (vrt. esim. LTK3: sitten hän puki vaatteet päälle) että englanninkielinen rakenne put the shoes on (MOT, 2015; OLDO, 2015). Englannin prepositio on vastaa itsenäisenä sanana suomen kielen sanaa päällä/päälle, joten englannin kieli saattoi vahvistaa lapsen alttiutta soveltaa asiayhteyteen nähden epäkonventionaalista suomalaista rakennetta.

Englannin kielen vaikutus syntaksiin saattoi tulla esiin myös joidenkin lasten ilmauksissa, jotka vaikuttivat vaillinaisilta tai keskeneräisiltä. Esimerkissä 7 kaksikielisen pojan kielellinen valinta voisi kuitenkin olla puhekielinen ilmaus, mutta se vaikuttaa suomalaisessa kontekstissa puhekieliseksikin epätyypilliseltä.

Esimerkki 7: Meni koiralle shhh

CB9: sitten hän meni hänen koiralle $\underline{\text { sshhh }}$

Meneminen ei tässä asiayhteydessä mitä ilmeisimmin tarkoittanut liikkumista, vaan lapsi viittasi pikemminkin sanomiseen tai eleeseen, jolla tarinan koiraa kehotetaan olemaan hiljaa. Ilmauksessa oli todennäköisesti kyse englannin kielen siirtymisestä (Lauranto, 
suullinen tiedonanto 21.8.2015). Englanninkielisessä epämuodollisessa kielessä on nimittäin olemassa ilmaus, go (like), jolla siteerataan suoraan jonkun puhetta (Long, 2014). Rakenne oli myös pojalla CB9 itsellään käytössä, kun hän ikään kuin siteerasi tarinan hahmoa: then he goes like shbh. Puhumiseen liittyvään mennä-sanan käyttöön ei taas suomessa löydy viitteitä sanakirjoissa. Lapsen ilmaisu oli saattanut toisaalta vahingossa jäädä vain vajaaksi. Siitä voisi puuttua verbi, kuten juuri sanomaan. Kertoakseen vastaavan kohtauksen sammakkotarinassa yksikieliset viisi- ja kuusivuotiaat tuottivat ilmauksia, joissa selvästi tuli esille verbaalinen toiminta: sitten toipoika sano shbh (LPV30); sitten si sano koilalle bys (LTV8); sitten se (.) poika käski koiran olla biljaa (LTK4).

Myös esimerkissä 8 pojan lause näyttää litteraatin perusteella jääneen kesken. Kerronnan prosodisten piirteiden perusteella kuitenkin vaikutti siltä, että ilmaisu oli kokonaisuudessaan tällaiseksi tarkoitettu.

\section{Esimerkki 8: Kiipesin kiven}

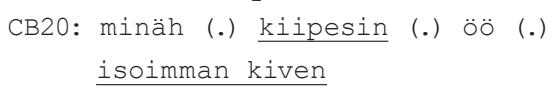

Esimerkkilauseen epätyypillistä morfosyntaktista muotoa saattoi hyvin selittää toisen kielen vaikutus, sillä poika tuotti englanniksi esimerkkilausetta muistuttavan lauserakenteen: so that the boy climbed (.) the biggest rock. Idiomaattinen ilmaus climb the hill/mountain tarkoittaa huipulle kiipeämisestä (OLDO, 2015). Poika oletettavasti siis tarkoitti myös suomenkielisellä lauseellaan kiipeämistä aivan suurimman kiven päälle. Miksi lapsi sitten valitsi genetiivimuotoisen akkusatiivin isoimman kiven eikä taivuttamatonta muotoa isoin kivi? Esimerkiksi englanninkielisessä I threw the ball-lauseessa suora objekti suomentuu muotoon heitin pallon. Näin ollen lapsi oli voinut päätellä, että samaa logiikkaa noudat- taen he climbed the rock vastaisi ilmausta kiipesinkiven. Suomen kiivetä-verbi on intransitiivinen eli kohteeton verbi. Lapsen sekaannusta voikin selittää juuri se, että toisin kuin suomessa, englannin kielessä samatarkoitteinen climb-verbi käyttäytyykin transitiivisesti ja saa suoran objektin. Kaksikielisestä lapsesta poiketen yksikieliset lapset kuvasivat tapahtumaa seuraavasti: se poika kiipes (.) kivelle (LTK7); poika kiipes: (.) kalliolle (LTK6); hän (.) kiipesi (.)ison kiven päälle (LTV8).

\section{Suomen kielen omaksumiseen liittyvät epätyypilliset ilmaukset}

Kielten välisen vaikutuksen lisäksi kaksikielisten lasten kerronnoista löytyi epätyypillisiä ilmaisuja, jotka liittyivät tulkintamme mukaan suomen kielen omaksumiseen. Poikkeavat valinnat olivat sanastollisia, morfologisia, morfosyntaktisia ja idiomaattisia sekä muita luokittelemattomia ilmauksia. Kaksikielisten ja verrokkilasten sanastotasoiset epätyypillisyydet olivat usein kuvissa esitettyjen esineiden tai olioiden nimien virheellisiä valintoja (esim. ämpäri po.purkki; kotka po.pöllö; härkä po.peura/hirvi/poro). Yksi kaksikielinen ja yksi viisivuotias lapsi käyttivät samaa sanaa lasi puhuessaan purkista. Myös joidenkin kaksikielisten ja viisivuotiaiden yksikielisten lasten verbivalinnat olivat semanttisesti epätäsmällisiä. Varsinkin verbi pudota tai tippua oli muutamille lapsille vaikea. Kaksi kaksikielistä ja kolme yksikielistä viisivuotiasta korvasi pudota tai tippua-sanan verbillä kaatua. Kuusivuotiaat verrokit osasivat puolestaan valita täsmällisen verbin: ja (.) poika alko- tippui puusta kun pöllö pelästytti sen (LPK6); ja ampiaispesä (.) tipabti maahan (LTK10).

On tosin vaikea arvioida, oliko kaksikielisten lasten kaatua-sanan käytön taustalla paitsi suomen kielen omaksumiseen liittyvä virheellinen valinta vai vaikuttiko sanavalintaan osittain myös englannin kieli. Esimerkik- 
si tyttö CG2 nimittäin esitti tarinan tilanteen englanniksi den (.) he falled down käyttäen fall-sanaa, joka suomentuu sekä kaatua että pudota (MOT, 2015). Täten englanninkielinen sana oli voinut siirtyä suomenkieliseen ilmaisuun vääränä käännöksenä: ja (.) sitten (.) hän kaatui puusta...

Kaikilla lapsiryhmillä esiintyi sekä morfologisia että morfosyntaktisia epätyypillisyyksiä, (esim. CB16: ja sitten (.) poika haisti haisunäädän ja se laitti kädet (.) sen+nenää po. haisto(i) ja laitto(i) ja LTV8: koira juoksi täydeltäänsä po. mahdollisesti täysiä tai täyttä vauhtia). Toisin kuin kieltenvälisestä vaikutuksesta johtuvissa tapauksissa, tässä tarkastelussa kaksikielisten ilmaisuista löytyi siis myös pelkästään morfologisesti epäkypsiä ilmauksia, kuten astevaihteluvirheitä (esim. CB16: sitten poika kiipes (.) tohon mäken (.) päälle po. mäen). Morfologista kypsymättömyyttä ilmeni neljällä kaksikielisellä lapsella, kun sitä esiintyi ikäverrokeista ainoastaan yhdellä ja vuotta nuoremmista kahdella lapsella. Verrokeista yksi kuusivuotias ja yksi viisivuotias lapsi tuotti kongruenssivirheitä (esim. LTK6: se poika saivat sen kiinni po. sai), joita kaksikielisten lasten valinnoissa ei esiintynyt.

Myös idiomaattisesti erikoisia ilmaisuja ilmeni kaikilla lapsiryhmillä (esim. CB16: maan sisältä po. maan alta, LPK2: ei kuulunut eikä nähty po. ei kuulunut eikä näkynyt, LTV7: taistella pöllöä vrt. taistella pöllöä vastaan). Lisäksi yhdellä kaksikielisellä ja yhdellä viisivuotiaalla verrokkilapsella oli samanlainen ilmaus (CB20: ja sitten kaikki ampiaiset byökkäsivät (.) koiraan ja LTV8: ampiaiset meinasivat byökätä koiraan). Englannin kielen vaikutus oli osaltaan voinut ohjata kaksikielisen lapsen valintaa. Poika CB20 käytti itse englanninkielisessä kerronnassaan englannille tyypillistä rakennetta: an' that the bees were attacking the do:g (ks. OLDO, 2015), joka muistuttaa myös lapsen tuottamaa poikkeavaa suomenkielistä muotoa.

\section{POHDINTA}

Tutkimuksen tarkoituksena oli tarkastella, miten englannin kielen omaksuminen heijastui kaksikielisten kuusivuotiaiden lasten kielellisiin valintoihin heidän kertoessaan sammakkotarinaa suomeksi. Tutkimuksen keskeisin tulos on, ettälähes kaikki kaksikieliset kuusivuotiaat lapset (10/11) tuottivat jonkinlaisia epätyypillisiä ilmaisuja suomeksi kertoessaan. Osassa niistä näytti ilmenevän englannin kielen vaikutus, kun taas osassa sellaista ei voitu havaita, vaan näiden ilmaisujen tulkittiin kuuluvan pääasiassa suomen kielen omaksumisprosessiin. Toisinaan oli kuitenkin hyvin vaikea erottaa, kumpi syy oli mahdollisesti epätyypillisen ilmauksen taustalla. Epätyypillisyyksiä löytyi yleisesti usealta kielelliseltä osa-alueelta.

Suurimmassa osassa (7/11) kaksikielisten lasten suomenkielisistä kertomuksista näkyi englannin kielen vaikutusta. Lasten kielelliset valinnat olivat kuitenkin melko yksilöllisiä. Englannin kielen ominaisuuksia näytti siirtyvän lasten suomen kieleen siitä huolimatta, että suomi oli heidän kotikielensä ja useimmiten vahvin kielensä. Kieltenvälistä vaikutusta on havaittu tapahtuvan useimmiten vahvemmasta tai aikaisemmin omaksutusta kielestä heikompaan tai myöhemmin omaksuttuun kieleen (esim. Yip \& Matthews, 2006; Korpilahti, 2010), mutta myös tämän tutkimuksen tulosten kaltainen päinvastainen vaikutus on tunnustettu jo pitkään (esim. Marian \& Kaushanskaya, 2007; Koda, 2008, s. 72; Yip \& Matthews, 2006). Elementtien siirtymisen suunnassa ei olekaan välttämättä aina kyse dominanssista (esim. Marian \& Kaushanskaya, 2007; Yip \& Matthews, 2006). Tutkimillamme lapsilla kieltenvälistä vaikutusta saattoi edesauttaa muun muassa englannin kielen vahva suotuisa status ${ }^{10}$ (Ritchie $\&$ Bhatia, 2013).

\footnotetext{
${ }^{10}$ Englannin kielen asemasta Suomessa tarkemmin ks.(Leppänen ym., 2009: 73-77, 89-90, 111-115; Dixon ym., 2012).
} 
Syynä englannin vaikutukseen saattoi joskus olla myös esimerkiksi se, että jotkin englannin kielen sanat tai rakenteet olivat lapsilla ehkä niin vahvoina mielessä, että heidän oli vaikea pystyä inhiboimaan eli estämään niitä tehtävätilanteessa (ks. Costa \& Sebastán-Gallés, 2014; Linck ym. 2008). Lapset saattoivat käyttää englannin kielen sanoja tai rakenteita myös tietoisesti ja kompensatorisista syistä (ks. Genesee ym., 2004, s. 77; Nicoladis \& Genesee, 1997). Yhdeksi syyksi kielten yhdistämiselle (engl. mixin/code-mixing) esitetäänkin sitä, että yhden kielen sanastopuutteita paikkaillaan toisesta kielestä löytyvillä vastineilla (esim. Nicoladis \& Genesee, 1997; Nicoladis \& Secco, 2000). Esimerkiksi splash-ilmauksen tuottaminen saattoi kahdella pojalla johtua yhtäältä siitä, ettei heillä ollut hallussa sopivaa ilmaisutapaa suomeksi tai se ei heillä heti tullut mieleen. Toisaalta kaksikielisille puhujille toisen kielen sanojen käyttö ja koodinvaihto ovat samankaltaisia ilmaisuvoimaisia keinoja kuin yksikielisillä sanavalintojen tekeminen (Grosjean, 1982, s. 150-152). Voikin olla, että pojat katsoivat englanninkielisen ilmaisun yksinkertaisesti kuvaavimmaksi vaihtoehdoksi tarinansa kohtaukseen.

Aineistossa yksi lapsi vaihtoi kieltä kesken tehtävän. Motiivina saattoi olla kyllästymisen ilmaiseminen tai se, että poika halusi tehdä selvän eron kerronnan ja siihen liittymättömien kommenttiensa välillä. Tätä tulkintaa tukee Meiselin (2004) yhteenveto kielenvaihtoa koskevista tutkimuksista: mitä kehittyneempi kielenkäyttäjä on sitä enemmän koodinvaihto alkaa ilmentää nimenomaan pragmaattista etevyyttä sen sijaan, että sillä vain helpotettaisiin viestintää (ks. myös Genesee ym., 2004, s. 104, 110-111). Tähän tutkimukseen osallistuneet lapset saattoivat kielellisillä valinnoillaan myös haluta ilmaista itseään ja persoonallisuuttaan (ks. Grosjean, 1982, s. 149-157). Erään tytön tapa käyttää suomessa samaa epäröintiäännettä kuin englannissa oli ehkä keino tuoda esiin omaa kaksikielistä identiteettiä.

Kaksikieliset lapset päätyivät toisinaan ikään kuin kääntämään idiomaattisia ilmaisuja suoraan suomeksi (esim. once (upon a time) there was ja yhden kerran (.) asui). Idiomaattiset ilmaukset ovatkin kielikohtaisia, ja niiden käytössä näkyy kielikulttuurin tuntemus (Nenonen, 2002, s. 2-6; Yorio, 1989). On ehdotettu, että ainakin sellaiset morfosyntaktiset valinnat, joiden tekeminen on sidoksissa kielenkäyttötilanteen pragmatiikkaan, ovat erittäin alttiita kielten väliselle vaikutukselle (Serratrice, 2007). Kieltenvälinen vaikutus näkyi tässä aineistossa useimmiten juuri idiomaattisissa ilmaisuissa ehkä siksi, että myös niiden käyttö liittyy kulttuurikohtaisten pragmaattisten ja tilannesidonnaisten säännönmukaisuuksien hallitsemiseen.

Kun englannista siirtyi fraaseja tai muita ilmaisutapoja suomen kieleen, kaksikieliset lapset näyttivät kuitenkin soveltavan niihin hallitsemiaan suomen yleissääntöjä (ks. Savinainen-Makkonen \& Kunnari, 2009). Esimerkiksi ilmaus the boy_climbed the biggest rock siirtyi suomeen muodossa minäh kiipesin isoimman kiven, eikä vaikkapa minä kiipesin isoin kivi. Poika siis tiesi, että suomessa sanojen kuuluu tällaisissa rakenteissa taipua, vaikka hän ei osannutkaan valita tavanomaista tapaa ilmaista asia. Lasten valinnat ehkä heijastivatkin heidän sen hetkistä ymmärrystään siitä, miten kieliä ja niiden muotoja voidaan käyttää merkitysten rakentamisessa (ks. Lauranto, 1997, s. 148-149, 168, 172).

Yli puolet lapsista kaikissa ryhmissä käytti suomen kielen oppimiseen liittyviä, aikuiskielestä poikkeavia muotoja. Vaikka ne olivat pääosin yksilöllisiä, kaksikielisten lasten ilmauksista löytyi muutama yhtäläisyys viisivuotiaiden yksikielisten lasten ilmausten kanssa. Mainittavin samankaltaisuus oli kaatuasanan käyttö tippua tai pudota -sanan sijaan 
kahdella kaksikielisellä tutkittavalla ja kolmella viisivuotiaalla verrokilla. Ikäeroa näiden kaksikielisten $(6 ; 7$ ja 6;8) ja viisivuotiaiden lasten $(5 ; 3,5 ; 4$ ja 5;5) välillä oli yli vuosi, joten samankaltaisuuden taustalla voitaisiin ajatella olevan samantasoinen suomen kielelle altistuminen. Kuitenkin myös englannin kielen vaikutus saattaa selittää kaksikielisten lasten ilmaisuja. On lisäksi huomattava, että koska kaksikielisiä lapsia ja verrokkeja oli keskenään eri määrät (myös eri sukupuolten osalta) ja koska heidän kerrontansa olivat eripituisia, lapsiryhmien vertailusta ei voida tämän aineiston perusteella tehdä päteviä johtopäätöksiä.

Kaksikielisessä ympäristössä kasvaminen saattaa viivästyttää sanaston ja morfosyntaksin kehittymistä ainakin yhdessä lapsen kielistä (Bialystok, 2001, 232; Zurer Pearson, 2009). Mahdollisena taustatekijänä joihinkin kaksikielisten lasten sanaston virheisiin saattoi sanaston hieman hidastuneen karttumisen ohella tai sen sijaan olla sananlöytämiseen liittyvät prosessit. Tätä ajatusta tukevat havainnot, joiden mukaan sanahaun vaikeudet ovat yleisempiä kaksikielisillä kuin yksikielisillä puhujilla jopa kaksikielisen henkilön vahvemmassa kielessä tai ensikielessä (Gollan \& Acenas, 2004; Ivanova \& Costa, 2007; Runnqvist, Gollan, Costa \& Ferreira, 2013).

Koska kielelliset valinnat ovat aina yhteydessä käyttökontekstiinsa, on oletettavaa, että myös aineistonkeruun kontekstilla on ollut vaikutusta lasten valintoihin (Halliday \& Matthiessen, 2004, s. 29; Shore, 1992, s. 19). Ensinnäkin esikoulu kerrontaympäristönä saattoi lisätä kieltenvälistä vaikutusta, sillä lapset olivat tottuneet käyttämään siellä englantia (ks. myös Marian ja Kaushanskay, 2006). Toiseksi aineisto kerättiin siten, että lapset kertoivat tarinansa peräjälkeen ensin englanniksi ja sitten suomeksi samalle tutkijalle. Kerrontojen välitön peräkkäisyys saattoi esimerkiksi vaikeuttaa äskettäin aktii- visena olleen englannin kielen inhiboimista suomeksi kerrottaessa ja siten edesauttaa englannin kielen piirteiden siirtymistä suomeen. Samankaltaisesti Meuter ja Alport (1999) havaitsivat, että heikommasta toisesta kielestä ensikieleen vaihtaminen häiritsi tutkittavien suoriutumista ensikielellä nimeämistehtävässä, oletettavasti koska toisen kielen aktivointi ja samalla ensikielen inhibitio jatkuivat tahattomasti yhä kielen vaihtamisen jälkeenkin. Jatkossa kerrontatutkimuksen voisikin toteuttaa muutoin samalla tavalla, mutta vaihtamalla kielten järjestystä, jolloin peräkkäisyydestä johtuvaa priming-efektiä voitaisiin arvioida. Kerrontojen järjestys ei kuitenkaan yksinään riitä selittämään kieltenvälistä vaikutusta, sillä havaintojemme mukaan myös englannin kielisiin kerrontoihin oli siirtynyt piirteitä suomen kielestä (ks. Alantie, 2015, s. 40).

Puheterapeuttisia arviointitapoja tai tutkimuksia suunniteltaessa kielten mahdollinen inhibitiovaikutus olisikin syytä ottaa huomion. Kerronta-aineistot kahdella eri kielellä kannattaisikin kerätä vaikkapa siten, että kerrontojen välissä lapsen kanssa puuhattaisiin hetki jotakin aivan muuta. Voisi olla edullista myös vaihtaa tutkijaa erikielisiä kerrontoja kerättäessä. Molempia kieliä osaavan kuulijan kanssa lapsi saattaa nimittäin vapaammin yhdistellä kieliään luottaen siihen, että hän tulee kyllä ymmärretyksi (Grosjean, 1982, s. 149-149; Korpilahti, 2010).

Kieltenvälisen vaikutuksen havaitseminen ja tulkinta on kaksikielisten lasten tutkimuksessa pulmallista (Gawlitzek-Maiwald \& Tracy, 1996). Vaikka voitaisiin sulkea pois lipsahduksen mahdollisuus, epätyypillisen ilmauksen taustalla saattaa olla kieltenvälinen vaikutus, kielellisten taitojen tasosta johtuva syy tai molemmat (Gawlitzek-Maiwald \& Tracy, 1996; Marian \& Kaushanskaya, 2006). Asiaa monimutkaistaa edelleen se, että englannin globaalin luonteen vuoksi siitä siirtyy ilmaisuja suomeen ja siten lapsen kieliympä- 
ristöön yleisemminkin (Lauranto, suullinen tiedonanto 21.8.2015). Lisäksi lähipiirin aikuisten ja muiden lasten mallit voivat vaikuttaa lapsen kieleen (ks. Korpilahti, 2010; Yip \& Mathews, 2006).

Koska kaksikieliselle kehitykselle on tavallista, että taidot jakautuvat epätasaisesti ensinnäkin eri kielten kesken mutta myös käyttötarkoituksen ja -kontekstin mukaan (Arkkila ym., 2013), olisi kielellistä tuottoa perusteltua tutkia erilaisissa diskursseissa. Olennainen tarkkailun kohde olisi arkinen keskustelutilanne, sillä myös kulttuuristen piirteiden tiedetään näkyvän kerronnan lisäksi erityisesti keskustelussa (Menyuk \& Brisk, 2005, s. 49-51). Puheterapeuttisessa arvioinnissa asiakkaan taitoja tulee lisäksi peilata tämän ikätason ja elämäntilanteen mukaisiin viestintätarpeisiin (esim. Suvanto, 2011). Valintoja olisikin syytä tutkia kielen eri tehtävien täyttymisen näkökulmasta (Halliday 1975; ks. myös Korpijaakko-Huuhka, 2011). Lisäksi havaintojen tekeminen lasten molemmista kielistä olisi tärkeää siksi, että puheterapeuttien tulisi kliinisessä työssään pyrkiä arvioimaan lapsen kummankin kielen käyttämistä ja tasoa (Arkkila ym., 2013). Puheterapeutin arvioon ohjautuvat Suomessa tällä hetkellä erityisesti sellaiset vieraskieliset lapset, jotka altistuvat kielellemme mennessään päivähoitoon 1-3-vuotiaina tai vanhempina. Kliinisen työn taustaksi tutkimusta kaivattaisiin näiden lasten osalta kiireellisesti (Arkkila ym., 2013).

\section{JOHTOPÄÄTÖKSET}

Tämän tutkimuksen tulosten mukaan kahden kielen vaikutuspiirissä kasvaminen näkyy kuusivuotiaiden lasten kielellisessä tuotossa. Suomenkielisessä kerronnassa esiintyvien epätyypillisten valintojen taustalla on mahdollisesti ainakin kaksi tekijää: kielispesifi englannin vaikutus suomeen ja suomen kielen omaksumisprosessin piirteet. Taustavaikuttajien erottaminen toisistaan ei ole yksinkertaista, ja ne luultavasti nivoutuvatkin toinen toisiinsa. Myöskään muiden taustatekijöiden tai lipsahdusten mahdollisuutta ei voida täysin sivuuttaa. Yleistettävien tulosten saamiseksi kaksikielisten lasten kielenkäyttöä tulisi tutkia suuremmilla otoksilla, laajemmilla aineistoilla ja vaihtelevissa diskursseissa sekä toisella tavalla toteutetuissa tutkimusasetelmissa.

Havaintojen perusteella voitaneen olettaa, että kaksikieliset lapset tuottavat osittain erilaisia ja ehkä jopa enemmän epätyypillisiä ilmaisuja kuin yksikieliset lapset. Jotkin kaksikielisten lasten suomen kielen omaksumiseen liittyvät epätyypilliset ilmaisut sen sijaan näyttivät muistuttavan heitä nuorempien verrokkilasten valintoja. Näihin seikkoihin olisi hyvä kiinnittää huomiota kaksikielisten lasten kielellisiä taitoja arvioitaessa. Puheterapeutin kliinistä työtä ajatellen tämän tutkimuksen yhteydessä esille nousseita muita tärkeitä pohdinnan kohteita ovat tutkimusympäristön sekä tutkimuskäytänteiden mahdollinen yhteys kieltenvälisen vaikutuksen esiintymisherkkyyteen.

\section{KIITOKSET}

Tahdomme esittää kiitoksemme tutkimukseen osallistuneille lapsille ja heidän perheilleen sekä päiväkotien henkilökunnalle. Kiitokset analyysikonsultaatioista Yrjö Laurannolle (HY), suomen kieltä opiskelleelle asiantuntijaryhmälle, englannin kielen opettajalle Veera Peterille sekä Tampereen logopedian henkilökunnalle ja lukuvuonna 2014-15 graduseminaariin osallistuneille opiskelijoille - heistä muutamille erityisesti. Lisäksi kiitämme artikkelin arvioitsijoita arvokkaasta palautteesta ja asiantuntevista neuvoista. 


\section{LÄHTEET}

Aalto, E, Latomaa, S. \& Suni, M. (1997). Suomi toisena ja vieraana kielenä - tutkittua ja keskusteltua. Virittäjä, 101, 530-562.

Alantie, S. (2014). Verb Usage in the Narratives of Six-Year-Old Bilingual Children. Englantilaisen filologian pro gradu -tutkielma. Tampereen yliopisto.

Alantie, S. (2015). "Yhden kerran oli poika": siirtovaikutuksia kertovan kielen valintoihin kuusivuotiailla suomea ja englantia omaksuvilla lapsilla. Logopedian pro gradu -tutkielma. Tampereen yliopisto.

Arkkila, E., Smolander, S. \& Laasonen, M. (2013). Monikielisyys ja kielellinen erityisvaikeus. Duodecim, 129, 200-207.

Bedore, L. M. \& Peña, E. D. (2008). Assessment of Bilingual Children for Identification of Language Impairment: Current Findings and Implications for Practice. The International Journal of Bilingual Education and Bilingualism, 11, 1-29.

Bialystok, E. (2001). Bilingualism in development: Language Literacy and cognition. New York: Cambridge University Press.

Chakraborty, R. (2015). An Overview of Research in Bilingualism: Publication Records and Global Needs. Perspectives on Global Issues in Communication Sciences and Related Disorders, 5, 67-74.

Costa, A. \& Sebastián-Gallés, N. (2014). How Does the Bilingual Experience Sculp the Brain? Nature Reviews Neuroscience, 15, 336-345.

Cummins, J. (2001). Bilingual Children's Mother Tongue: Why is it important for education? Sprogforum, 7(19), 15-20.

De Houwer, A. (2004) [1995]. Bilingual language acquisition. Teoksessa P. Flectcher \& B. MacWhinney (toim.), The Handbook of Child Language, (s. 219-250). Oxford: Blackwell

Dixon, L. Q., Wu, S. \& Daraghmeh, A. (2012). Profiles in Bilingualism: Factors Influencing Kindergartners' Language Proficiency. Early Childhood Education Journal, 40, 25-34.

Eriksson, P. \& Rajala, E. (2014). Miten kielellisesti tyypillisesti kehittyneet 6-7-vuotiaat lapset tuottavat ja ymmärtävät sammakkotarinan? Alustavat ikänormit. Logopedian pro gradu -tutkielma. Tampereen yliopisto.
Gawlitzek-Maiwald, I., \& Tracy, R. (1996). Bilingual Bootstrapping. Linguistics, 34, 901-926.

Genesee, F., Paradis, J. \& Crago, M. (2004). Dual Language Development and disorders: A Handbook on Bilingualism \& Second Language Learning. Baltimore: Paul H. Brookes Publishing Co. Gollan, T. \& Acenas, L.(2004). What is a TOT? Cognate and translation effects on tip-of-thetongue states in Spanish-English and TagalogEnglish bilinguals. Journal of Experimental Psychology: Learning, Memory and Cognition, 30, 246-269.

Hakulinen, A., Kauppinen, A., Leiwo, M., Paunonen, H., Räikkälä, A., Saukkonen, P., ... Alho, I. (2004). Kieli ja sen kieliopit (5. painos). Helsinki: Edita Prima Oy.

Halliday, M. A. K. (1973). Explorations in the Functions of Language. Lontoo: Arnold.

Halliday, M. A. K. (1975). Learning How to Mean: Explorations in the Development of Language. Lontoo: Arnold.

Halliday, M.A.K. (1978) Language as Social Semiotic: The Social Interpretation of Language and Meaning. Edward Arnold: London.

Halliday, M. A. K. \& Matthiessen, C. M. I. M. (2004). An Introduction to Functional Grammar. 3. painos. Lontoo: Arnold.

Halmari, H. (1997). Government and codeswitching explaining American Finnish. Philadelphia: J. Benjamins.

Halmari, H. (2005). "I'm forgetting both": L1 maintenance and codeswitching in FinnishEnglish language contact. International Journal of Bilingualism, 9, 397-433.

Halmari, H. \& Smith, W. (1994). Code-switching and register shift: Evidence from FinnishEnglish child bilingual conversation. Journal of Pragmatics, 21, 427-445.

Hoffmann, C. (1991). An Introduction to Bilingualism. Lontoo: Longman.

Ijalba, E., Obler, L. \& Chengappa, S. (2013). Bilingual Aphasia: Theoretical and Clinical Considerations. Teoksessa T. K. Bhatia \& W. C. Ritchie (toim.), The Handbook of Bilingualism and Multilingualism (2.painos), (s.61-83). Chichester: Wiley-Blackwell.

Ivanova, I. \& Costa, A. (2008). Does bilingualism hamper lexical access in speech production? Acta Psychologica, 127, 277-288. 
Kaivapalu, A. (2005). Lähdekieli kielenoppimisen apuna. Jyväskylä: Jyväskylä studies in Humanities 44.

Kielitoimiston sanakirja. (2015). (Kotimaisten kielten keskus ja Kielikone Oy). Osoitteessa http://www.kielitoimistonsanakirja.fi/. Luettu 31.5.2015.

Koda, K. (2008) Impacts of prior literacy experience on second language learning to read. Teoksessa K. Koda \& A.M. Zehler (toim.), Learning to read across languages; Cross-linguistic relationships in first- and second language literacy development, (s. 68-96). New York: Routledge.

Kohnert, K. (2010). Bilingual children with primary language impairment: Issues, evidence and implications for clinical actions. Journal of Communication Disorders, 43, 456-473.

Korpijaakko-Huuhka, A-M. (2011). Kielenkäyttötehtävien arvioinnin suuntaviivoja. Teoksessa S. Loukusa \& L. Paavola (toim.), Lapset kieltä käyttämässä:pragmaattisten taitojen kehitysja sen häiriöt, (s. 211-228). Jyväskylä: PS-kustannus.

Korpilahti, P. (2007). Lapsen monet reitit kaksikieliseksi - haasteita ja mahdollisuuksia. Teoksessa S. Latomaa (toim.), Oma kieli kullan kallis. Opas oman äidinkielen opetukseen, (s. 26-35). Helsinki: Opetushallitus.

Korpilahti, P. (2010). Kaksikielisyys ja kielihäiriöt. Teoksessa P. Korpilahti, O. Aaltonen \& M. Laine (toim.), Kieli ja Aivot, (s. 146-151). Turku: Turun Yliopisto.

Kunnari, S. \& Savinainen-Makkonen, T. (2012). Äänteellinen kehitys ja sen kaudet. Teoksessa S. Kunnari \& T. Savinainen Makkonen (toim.), Pienten sanat: lasten äänteellinen kehitys, (s. 65-68). Jyväskylä: PS-Kustannus.

Lauranto, Y. (1997). Ensi askeleita paikallissijojen käyttöön: espanjankielisten suomenoppijoiden sisä- ja ulkopaikallissijat konseptuaalisen semantiikan näkökulmasta. Helsinki: Helsingin yliopiston suomen kielen laitos.

Lauranto, Y. (2015). Suullinen tiedonanto. 21.8.2015.

Leiwo, M. (1986). Lapsen kielen kehitys (2. painos). Helsinki: Gaudeamus.

Leppänen, S., Pitkänen-Huhta, A., Nikula, T., Kytölä,S., Törmäkangas, T., Nissinen, K., ... Jousmäki, H. (2009). Kansallinen kyselytutkimus englanninkielestä Suomessa: käyttö, merkitys ja asenteet. Jyväskylä: Jyväskylän Yliopisto.
Linck, J. A., Hoshino, N. \& Kroll, J.K. (2008). Cross-language lexical processes and inhibitory control. The Mental Lexicon, 3, 349 -374.

Lindstromberg, S. (2010). English Prepositions Explained. Philadelphia: John Benjamins B. V.

Long, S. (2014). A possible explanation for the emergence of quotative "like" in American English. Osoitteessa: https://technaverbascripta. wordpress.com/2014/04/28/a-possibleexplanation-for-the-emergence-of-quotativelike-in-american-english/. Luettu: 4.7.2015.

Marian, V. \& Kaushanskaya, M. (2007). Crosslinguistic transfer and borrowing in bilinguals. Applied Psycholinguistics, 28, 369-390.

Mayer, M. (1969). Frog, Where Are You? New York: Dial Books for Young Readers.

Meisel, J.M. (2004) [2000]. Early differentiation of languages in bilingual children. Teoksessa L. Wei (toim.), The Bilingualism Reader, (s. 344369). Lontoo: Routledge.

Menyuk, P. \& Brisk, M. E. (2005). Language Development and Education: Children with Varying Language Experience. Basingstoke: Palgrave Macmillan.

Mertanen, H. \& Vaarma, M. (2015). Ku oli semmonen poika, jolla oli sammakko - Kielellisesti tyypillisesti kehittyneiden 5-vuotiaiden lasten kerrontataidot. Logopedian pro gradu -tutkielma. Tampereen yliopisto.

Meuter, R. F. I. \& Allport, A. (1999). Bilingual Language Switching in Naming: Asymmetrical Costs of Language Selection. Journal of Memory and Language, 40(1), 25-40.

Morris, M. \& Korpijaakko-Huuhka, A-M. (2009). Kaksikielisten vanhempien kielen käyttö lapselle suunnatussa puheessa: neljä tapaustutkimusta. Puhe ja Kieli, 29, 15-25.

MOT, suursanakirja. (2015). (Kielikone Oy). Saatavilla https://mot.kielikone.fi/mot/uta/ netmot.exe. Luettu 7.10.2015.

Nenonen, M. (2002). Idiomit ja leksikko: Lausekeidiomien syntaktisia, semanttisia ja morfologisia piirteitä suomen kielessä. Joensuu: Joensuun yliopisto.

Nicoladis, E. \& Genesee, F. (1997). Language Development in Preschool Bilingual Children. Journal of Speech-Language Pathology and Audiology, 21, 258-270.

Nicoladis,E., Rose, A. \& Foursha-Stevenson, C. (2010). Thinking for speaking and cross-lin- 
guistic transfer in preschool bilingual children. International Journal of Bilingual Education and Bilingualism, 13, 345-370.

Oxford Language Dictionaries Online. (2015). (Oxford University Press). Osoitteessa http://www.oxforddictionaries.com/. Luettu 7.10 .2015

Paradis, J. (2010). Bilingual Children's Acquisition of English Verb Morphology: Effects of Language Exposure, Structure Complexity, and Task Type. Language Learning, 60, 651-680.

Place, S. \& Hoff, E. (2011). Properties of Dual Language Exposure that Influence the 2-YearOlds' Bilingual Proficiency, Child Development, 82, 1834-1849.

Poplack, S., Wheeler, S. \& Westwood, A. (1989). Distinguishing Language contact phenomena. World Englishes, 8, 389-406.

Rapo, M. (2012). Suomi ilman maahanmuuttajia. Osoitteessa http://www.stat.fi/artikkelit/ 2012/art_2012-03-12_008.html?s=1. Luettu 27.7.2014.

Riionheimo, H. (2010). Kielten sulautuminen suomen ja viron kontaktissa. Teoksessa Kaivapalu, A., Muikku-Werner, P. \& Sepper, M-M. (toim.), Lähivõrdlusi. Lähivertailuja 20, (s. 218-239). Tallinna: Eesti rakennusduslingvistika ühid.

Ritchie, W. C. \& Bhatia, T. K. (2013). Social and Psychological Factors in Language Mixing. Teoksessa T. K. Bhatia \& W. C. Ritchie (toim.), The Handbook of Bilingualism and Multilingualism (2. painos), (s. 745-769). Chichester: Wiley-Blackwell.

Roininen, H. (2014). Verbien käyttö 6- ja 7-vuotiaiden lasten kertomuksissa. Vertaileva ryhmätutkimus. Logopedian pro gradu -tutkielma. Tampereen yliopisto.

Sajavaara, K. (2006). Kontrastiivinen analyysi, transfer ja toisen kielen oppiminen. Teoksessa A. Kaivapalu \& K. Pruuli (toim.), Lähivertailuja 17, Jyväskylä Studies in Humanities 53, (s. 9-25). Jyväskylä: Jyväskylän yliopisto.

Savinainen-Makkonen, T. \& Kunnari, S. (2009). Puheen, kielen ja kommunikoinnin kehitys lapsuudessa. Teoksessa O. Aaltonen, R. Aulanko, A. Iivonen, A. Klippi, M. Vainio (toim.), Puhuva ibminen: pubetieteiden perusteet, (s. 114-121). Helsinki: Otava.
Serratrice, L. (2007). Cross-linguistic influence in the interpretation of anaphoric and cataphoric pronouns in English-Italian bilingual children, Bilingualism: Language and Cognition, 10, 225-238.

Shore, S. (1992). Aspects of a Systemic-Functional Grammar of Finnish. Sydney: Macquarie University.

Silvén, M. (2010). Lapsen kaksikielinen varhaiskehitys. Teoksessa P. Korpilahti, O. Aaltonen \& M. Laine (toim.), Kieli ja Aivot, (s. 139-145). Turku: University of Turku.

Smolander, S., Kunnari, S. \& Laasonen, M. (2016). Näkökulmia kielellisten taitojen arviointiin ja kielellisen vaikeuden tunnistamiseen monikielisellä lapsella. Puhe ja Kieli, 36, 57-75.

Suvanto, A. (2011). Leikki-ikäisen lapsen kielenkäyttötaitojen kehittäminen. Teoksessa S. Loukusa \& L. Paavola (toim.), Lapset kieltä käyttämässä: pragmaattisten taitojen kehitys ja sen bäiriöt. (s. 279-289). Jyväskylä: PS-Kustannus.

Suvanto, A. (2012). Lapsi tarinaa rakentamassa: Kielihäiriöisten lasten kerrontataidot ja niiden kuntoutuminen. Oulu: Oulun yliopisto.

Verhoeven, L. (2010) [2004]. Bilingualism and Narrative Construction. Teoksessa S. Strömqvist \& L. Verhoeven (toim.), Relating Events in Narrative Vol. 2: Typological and Contextual Perspectives, (s. 435-454). Mahwah (N.J.): Lawrence Erlbaum.

VISK = Ison suomen kieliopin verkkoversio. (2008). (päätoim. A. Hakulinen). Osoitteessa http://scripta.kotus.fi/visk/etusivu.php. Luettu 7.10.2015

Vygotski, L. S. (1982) [1931]. Ajattelu ja kieli. K. Helkama ja A. Koski-Jännes (suom.). Espoo: Weilin+Göös.

Wei, L. (2004) [2000]. Dimensions of bilingualism. Teoksessa L. Wei (toim.), The Bilingualism Reader, (s. 3-25). Lontoo: Routledge.

Weinreich, U. (1963) [1953]. Languages in Contact: findings and problems. Hague: Mouton.

Yip, V. \& Matthews, S. (2000). Syntactic Transfer in a Cantonese-English Bilingual Child. Bilingualism: Language and Cognition, 3, 193-208.

Yip, V. \& Matthews, S. (2006). Assessing Language Dominance in Bilingual Acquisition: A Case for Mean Lenght Utterence. Language Assessment Quaterly, 3, 97-116. 
Yorio, C. A. (1989). Idiomacity as an indicator of second language proficiency. Teoksessa $\mathrm{K}$. Hyltenstam \& L. K. Obler (toim.), Bilingualism Across the Lifespan, (s. 55-72). Cambridge: Cambridge University Press.
Zurer Pearson, B. (2009). Children with two languages. Teoksessa E. L. Bavin (toim.), The Cambridge Handbook of Child Language, (s. 379-398). New York: Cambridge.

\section{CROSS-LINGUISTIC INFLUENCES IN THE FROG-STORY NARRATIONS OF SIX-YEAR-OLD CHILDREN ACQUIRING FINNISH AND ENGLISH}

Sonja Alantie, University of Tampere

Anna-Maija Korpijaakko-Huuhka, University of Tampere

Leena Rantala, University of Tampere

This study describes some of the linguistic features used by 11 six-year-old bilingual children in a narrative task. All the children spoke Finnish as their first language and had begun to acquire English at the latest at the age of four. The objective of the study was to discover whether and how the English language possibly influenced the children's linguistic choices when telling a story in Finnish. This was performed by observing the atypical expressions the bilingual children produced in their narratives and further by comparing these expressions to the language usage of monolingual six-year old peers $(\mathrm{n}=10)$ and monolingual five-year-olds $(\mathrm{n}=12)$ in the same task. Nearly all bilingual children produced atypical expressions which represented mainly either 1) cross-linguistic interaction or 2) inaccuracies that cannot be traced to the influence of English but are here rather considered to be connected to Finnish language acquisition. Overall, the bilingual children produced atypical expressions slightly more often than the monolingual children. Based on the findings of cross-linguistic interaction the bilingual children used some expressions that were unique compared to the monolingual children's expressions. However, some of the bilingual children's choices, which were connected to Finnish language acquisition, were very similar to those of the five-year-old monolingual children. In relation to the clinical work of speech-language pathologists and future research, this study suggests that context and practises in collecting the data may influence the susceptibility of cross-linguistic features in narrative discourse..

Keywords: bilingual children, cross-linguistic interaction, linguistic choice, narrative language, systemic-functional linguistic theory 